\title{
Havalandırma Yöntemlerinin, Çalışan Memnuniyeti Üzerindeki Farklı Etkilerinin İncelenmesi
}

\author{
Gaye SAMSUNLU $^{1 *}$, Funda Bahar KAYA ${ }^{2}$
}

Öz

Ofis çalışanlarının memnuniyetini etkileyen fiziksel şartlardan havalandırmanın, farklı yöntemlerle gerçekleştirilmesi, çalışanlar üzerinde farklı etkiler oluşturmaktadır. Aktif ve pasif olarak ikiye ayrılan, bazı durumlarda entegre olarak da kullanılabilen havalandırma sistemlerinden hangisinin kullanıcılar üzerinde daha olumlu etkiye sahip olduğunun bilinmesinin, havalandırma sistemi seçiminde önemli rol oynayacağı düşünülmektedir. Ofis çalışanlarının sağlıklı ve memnun olmaları, bireysel mutluluklarının yanında iş verimliliklerini de artırmaktadır. Çalışan memnuniyeti açısından en olumlu havalandırma sistemi seçimi için yapılan tespit çalışması kapsamında öncelikle temel tanım ve kavramların incelenmesi adımı gerçekleştirilmektedir. Ardından, belirlenen sınırlar dahilinde yapılan literatür taraması ile elde edilen verilerden anlamlı bir sonuç elde edilmesi beklenmektedir. Ancak, verilerin sonuca ulaşmakta yetersiz kalması halinde, yeni bir veri toplama çalışması önerisinde bulunması hedeflenmektedir.

Anahtar Kelimler: Çalışan memnuniyeti, aktif havalandırma, pasif havalandırma, WELL, yeşil bina

\section{Analysis of the Different Effects of Ventilation Methods on Employee Satisfaction}

\begin{abstract}
The fact that ventilation, which is one of the physical conditions that affect the satisfaction of office employees. However using different methods creates different effects. It is thought that knowing which of the ventilation systems, which are divided into active and passive ventilation systems, which can also be used as integrated in some cases, has a more positive effect on the users, will play an important role in the selection of the ventilation system. The healthy and contented office staff increases their work efficiency as well as their individual happiness. Within the scope of the determination study for the selection of the most favorable ventilation system in terms of employee satisfaction, first of all, the basic definitions and concepts are examined. Then, a meaningful result is expected to be obtained from the data obtained through the literature review conducted within the specified limits. However, if the data are insufficient to reach the conclusion, it is aimed to suggest a new data collection study.
\end{abstract}

Keywords: Employee satisfaction, active ventilation, passive ventilation, WELL, green building

\footnotetext{
${ }^{1}$ Mimar Sinan Güzel Sanatlar Üniversitesi, Fen Bilimleri Enstitüsü, İç Mimarlık Ana Bilim Dalı

${ }^{2}$ Mimar Sinan Güzel Sanatlar Üniversitesi, Mimarlık Fakültesi, İç Mimarlık Bölümü

*ilgili yazar/Corresponding author: gaye.samsunlu@aparat.com.tr

Gönderim Tarihi: 21.01.2020

Kabul Tarihi: 10.12 .2020
} 


\section{GíRiş}

Ofis binası çalışanlarının memnuniyeti, yapılan işin niteliğinden ve fiziksel koşullardan etkilenmektedir. Yokluğunun çalışmayı olanaksız kıldığı havalandırma, çalışanın karşı karşıya kaldığı önemli fiziksel koşullardan biri olarak ortaya çıkmakta ve gerçekleştirilme yönteminin çalışan memnuniyeti üzerinde farklı etkileri olduğu bilinmektedir.

Aktif ve pasif havalandırma olarak ele alınan iki ana yöntemle ilgili, diğerine göre daha sağlıklı ve dolayısıyla memnuniyet artırıcı olduğunu sunan araştırmalar bulunmakta ve bu yaklaşımlar yine kendi içinde enerji tüketiminin daha az olduğu bulguları ile desteklenmektedir.

Yeşil Bina Raporunda bulunan değerlendirmeye göre; havalandırmanın aktif olarak gerçekleştirilmesi, enerji harcamalarının azaltılması yönünde önemli bir yaklaşım olarak kabul edilmektedir. Bu nedenle, pasif havalandırma binaya yük olarak görülmekte, kullanıcıların konforlu kabul edilen havalandırma değerleri içerisinde kalmasının sağlanması da aktif havalandırma ile daha rahat kontrol altında tutulabileceği ve kullanıcılar için standart bir binaya göre daha sağlıklı iç hava koşulları sağladığı öngörülmektedir . ${ }^{3}$ Diğer taraftan, yapıların geleneksel pasif iklimlendirme yöntemleri kullanılarak tasarlanmasının enerji tüketimini baştan düşürdüğü ve kullanıcılara daha sağlıkıı iç hava koşulları sunuyor olması görüşü de savunulmaktadır. ${ }^{4}$

$\mathrm{Bu}$ çalışma ile amaçlanan, gelecekte havalandırma yöntemi seçimlerine katkıda bulunabilmesi için, hangi yöntemin, çalışan memnuniyetini daha olumlu yönde etkilediğini tespit etmektir. Bu amaç doğrultusunda; çalışan memnuniyeti, aktif ve pasif havalandırma kavramları, iç hava koşullarını belirleyen standartlar ve denetim sistemleri incelenip, spesifik olarak havalandırma yöntemi ile kullanıcı memnuniyeti ilişkisinin ele alındığı akademik çalışmalar taranacaktır. Eldeki verilerin yeterli olmaması durumunda ise yeni bir veri toplama yöntemi önerilmesi hedeflenmektedir.

\section{GENEL TANIM VE KAVRAMLAR}

Mevcut verilerin yeterli olup olmadığının tespiti ve yeterli olmadığı sonucuna ulaşılması halinde, yeni veri toplama yöntemi önerilebilmesi için öncelikle konuya ilişkin genel kavramların incelenmesi gerekmektedir.

\section{1. Çalışan memnuniyeti}

Çalışan memnuniyeti konusu, literatürde iş tatmini olarak da anılmaktadır. Kavram ilk olarak 1920'lerde farklı ücret sistemlerinin geliştirilmesi ile çalışan beklentilerinin karşılanması sebebi ile karşımıza çıkmakta, 1930-1940'lı yıllarda neoklasik yaklaşımla birlikte önemi anlaşılmaya başlanmaktadır. Yakın geleceğe kadar çalışanın veriminin, kullandığı makinanın ya da yaptığı işin bir parçası olarak görülüyor olması nedeniyle örgütsel verimliliğin nasıl artırılacağı düşüncesi egemen iken, güncel yönetim anlayışı içinde çalışanın, artık bir işletmenin sahip olabileceği en değerli kaynak olarak kabul edilmeye başlandığı görülmektedir. ${ }^{5}$

\footnotetext{
${ }^{3}$ Erten, D., Yeşil Bina Raporu, Sürdürülebilir Üretim ve Tüketim (REC)Yayınları, https://recturkey.files.wordpress.com/2017/02/yesil-binalar.pdf, 08.01.2020. s.n.y.

${ }^{4}$ Yüksek, İ., Esin, T., Yapılarda Enerji Etkinliği Bağlamında Doğal Havalandırma Yöntemlerinin Önemi, Tesisat Mühendisliği, Sayı 125, İstanbul, 2011 s.n.y.

${ }^{5}$ Telman, N., Ünsal, P., Çalışan Memnuniyeti, Epsilon Yayınevi, İstanbul, 2004. s.13
} 
Genel olarak kavram, çalışanın işinden duyduğu memnuniyetin bir göstergesi ve işine karşı beslediği olumlu tutumlar olarak tanımlanabilmektedir. Çalışanın beklentilerinin karşılanma derecesi ve yapılan iş sonucu elde edilen maddi veya manevi çıkarlar, tatminin oluşmasında önemli unsurlar olarak ortaya çıkmaktadır. ${ }^{6}$

İş verimliliğini artırmanın yolunun, sağlıklı ve iş doyumu sağlanmış çalışanlardan geçmekte olduğu ise seneler içerisinde değer kazanmış bir tespit olarak karşımıza çıkmakta, iş doyumunu açıklamak için çok sayıda teorik ve gözleme dayalı çalışmalar yapıldığı görülmektedir. Maslow'un (1954) İhtiyaçlar Hiyerarşisi Teorisi, Herzberg'in (1959) Çift Etmen Teorisi, Thomas ve Griffin'in (1983) Sosyal Etki Teorisi, Kirkaldy ve Cooper (1993) tarafından incelenmiş iş doyumu-yaşam doyumu ilişkileri gibi araştırma ve çalışmalar, konuyla ilgili tespitlerin yapılmasında önemli rol sahibi olmaktadır. Herzberg'in Çift Etmen Teorisi'ne göre, iş hayatında kullanıcı memnuniyetini belirleyen iki temel faktör bulunmaktadır. Birincisi, başarı, tanınma gibi unsurları içinde barındıran motive edici faktördür. İşin çalışma koşulları ile ilgili olan ikinci faktörü de "hijyen faktörler" olarak adlandırmaktadır. İç çevre koşullarının, çalışma koşulları içeriğinde bulunması sebebi ile kullanıcı memnuniyeti faktörlerinden ikincisinin tanımına girdiği belirlenmektedir. İlk faktörün tamamlanması memnuniyet yaratırken, yokluğu memnuniyetsizliğe sebep olmamaktadır. İkinci faktörde ise, yokluğu memnuniyetsizliğe yol açarken, eksikliğinin tamamlanması tatminin sağlanması anlamına da gelmemektedir. ${ }^{7} \mathrm{Bu}$ araştırmalar üzerinde pek çok yorum yapılmtadır. Ancak çalışanın mutsuz olmaması için onun dışında olan şartların doğru oluşturulması, motive edilebilmesi için de çalışan ile bireysel ilişkili unsurların sağlanması gerektiği söylenebilmektedir. ${ }^{8}$

\subsection{Aktif ve pasif havalandırma}

Kapalı bir yerin havasını değiştirmek amacıyla çeşitli yöntemler ve araçlar kullanarak dışarıdan temiz hava verme, kullanılan havayı dışarı atma veya hava akımı oluşturma işlemine havalandırma denilmektedir. ${ }^{9}$

Aktif havalandırma, mekâna havanın cebri olarak makine yardımı ile alınması, pasif havalandırma ise, mekanik araçlar kullanılmadan hava hareketiyle kapalı mekanlara temiz hava sağlanması olarak tanımlanabilmektedir.

Doğru havalandırmadan beklenenin, taze havanın sağlanması, ısıtıması ve temizlenmesi olması sebebi ile öncelikle kişi başına gerekli taze hava miktarının tespit edilmesi gerekliliği görülerek, 1836 senesinde Tretgold tarafından metabolik taze hava intiyacı ile ilgili ilk tespitlerin yapıldığı bilinmektedir. Bu konuda binalarda uygulanacak ilk standartlar ise Amerikan Isıtma ve Havalandırma Mühendisleri Derneği (ASHRAE) tarafından 19. yüzyılın sonunda oluşturularak; ${ }^{10}$ ilk kişi başı hava ihtiyacının $2,5 \mathrm{~L} / \mathrm{s}$ olarak belirlendiği bilinmektedir. İlerleyen seneler içerisinde, yeni standartlar kullanılmaya başlandığı, kişi başı hava intiyacının da, sigara içilmeyen çalışma ortamlarında 10 L/s'ya kadar yükseldiği görülmektedir. ${ }^{11}$ Havalandırma şartlarının doğru olarak karşılanması için, ihtiyaç duyulan hava miktarının yanı sıra, havada

\footnotetext{
${ }^{6}$ Çabukel, R., Çalışan Memnuniyeti Analizleri, İstanbul Üniversitesi, Soysal Bilimler Enstitüsü, Çalışma Ekonomisi ve Endüstri İlişkileri Ana Bilim Dalı, Yüksek Lisans Tezi, İstanbul, 2008. s.n.y.

${ }^{7}$ Telman, N., Ünsal, P., Çalışan Memnuniyeti, Epsilon Yayınevi, İstanbul, 2004.s.15, s.40

${ }^{8}$ Telman, N., Ünsal, P., Çalışan Memnuniyeti, Epsilon Yayınevi, İstanbul, 2004.s.15, s.15

${ }^{9}$ Polat, A., Mekanik Tesisat Komisyonu, Havalandırma ve İklimlendirme Semineri, TMMOB, İzmir, 2017. s.n.y.

${ }^{10}$ ASHVAE Founding Meeting 1894, https://www.ashrae.org/about/mission-and-vision/ashrae-industry-history, 10.01.2020. s.n.y.

${ }^{11}$ Bulgurcu, H., Havalandırma Tekniği, Balıkesir, 2015, https://silo.tips/download/havalandirma-tekn-do-dr-hseyinbulgurcu-balkesir-2015\#, 10.01.2020. s.n.y.
} 
bulunması kabul edilebilir CO2 konsantrasyonun ve sağlıklı ortam sıcaklığının sınırları da 'Hava Kalitesi değerlendirme ve Yönetimi' yönetmeliği ile genel olarak belirlenmektedir. ${ }^{12}$ Sertifika sistemlerinin yerine getirilmesini istediği koşullarda, eğer yerelleştirilmiş bir muadili kullanılmıyor ise bu yönetmelik ile farklııklar gözlemlenebilmektedir.

\section{3. İç ortam hava kalitesine yönelik standartlar ve denetim sistemleri}

İç Ortam hava kalitesinin belirlenmesi için Amerika ve Avrupa kıtalarında farklı yaklaşımlar olduğu bilinmektedir. ASHRAE (American Society of Heating Refrigerating and Air Conditioning Engineers) standardı daha çok kişi başına taze hava ihtiyacıyla veya ortamın havalanmasıyla ilgili hesaplarını yapmakta ve dış havanın temiz olduğu varsayımı ile yola çıkmaktadır. Avrupa'daki standartlar ise, ortamı kalite sınırlarına ayırmakta, bu kalitelere göre havalanma miktarını tayin etmektedir. İç ve dış hava kaliteleri göz önüne alınarak hesaplamalar yapılmaktadır.

Türkiye'de ise Türk Standartları Enstitüsü tarafından hazırlanan TSE TS CR 1752 standardı yürürlüktedir ve tamamen Avrupa standartlarını yansıtmaktadır. ${ }^{13}$

Binaların henüz proje aşamasında hangi standardı kullanacağı, işverenin ve proje firmasının genel kararlarının yanı sıra, başvurulacak bir sertifika sistemi olup olmaması ile de belirlenmektedir. Türkiye'de mekanik projelerin hazırlanması ve mesleki olarak denetlenmesi esaslarında, uyulması gerekli standart konusunda bir yaptırım bulunmamaktadır. ${ }^{14}$ Ancak, yeşil bina sertifikalarından birine ya da WELL sertifikasına başvuruluyorsa, ilgili sertifikanın denetleme koşullarında bulunan standart tanımı dikkate alınmaktadır.

Yeşil bina sertifika sistemlerinden LEED için uygulanması beklenen standart ASHRAE iken, BREAM için BS ISO 1600 standartları esas alınmaktadır. ${ }^{15}$ Yeşil bina sertifika sistemlerinden farklı olarak WELL sertifika sistemi öncelikli olarak ASHRAE standardını kullanmakla birlikte, diğer havalandırma standartlardan da çeşitli kuralları kendi standart kitabında bulundurmaktadır.

LEED ve BREAM yeşil bina sertifika sistemlerinin odağında binanın kendisi bulunmaktadır. Yüzyılın en yeşil hareketlerinden biri olarak da kabul edilen yeşil bina sertifika sistemlerinin dünyaya inşaat sektörü yoluyla katkısı çok büyük olmakla beraber, sertifika almış bir binada kullanıcıların, standartların yerine getirilmiş olması üzerinden memnuniyeti beklenmektedir. ${ }^{16}$

Diğer taraftan, WELL sertifika sisteminde, insan sağlığını ve konforunu bina uygulamalarının ön saflarına yükseltmenin ve sadece gezegen için değil, insanlar için de daha iyi olan binaları yeniden keşfetmenin yolunun, binalardaki insanlara odaklanmak olduğu düşüncesi hâkimdir. Mekanların bireyler üzerindeki etkileri hakkında yapılmış araştırmaların kapsamlı olarak incelenmesine dayandırılan sistemde, binada belirli oranda açılır pencere bulunması, dolayısıyla pasif

\footnotetext{
${ }^{12}$ Hava Kalitesi Değerlendirme ve Yönetimi Yönetmeliği, 2008, Resmî Gazete, 26898, 06.06.2008. s.n.y.

${ }^{13}$ Çilingiroğlu, S., İç Hava Kalitesi, Tesisat Mühendisliği Dergisi, İstanbul, 2010. s. 23-42

${ }^{14}$ Proje (Mekanik, Tesisat, Asansör, A.İ.T.M.) Hazırlama ve Mesleki Denetim Esasları, TMMOB Makine Mühendisleri Odası, Ankara, 2008. s.n.y.

${ }^{15}$ Görgün, B., Enerji Verimli Yeşil Bina Sertifikasyonunda Yol Haritasının Belirlenmesi İçin LEED ve BREEAM Örneklerinin İncelenmesi, İstanbul Teknil Üniversitesi, Fen Bilimleri Enstitüsü, Mimarlık Ana Bilim Dalı, Yüksek Lisans Tezi, İstanbul, 2012. s.n.y.

${ }^{16}$ Watt, M., Understanding LEED, WELL and the Differences, https://eponline.com/articles/2019/04/11/understandingleed-well-and-the-differences.aspx , 04.01.2020 s.1
} 
havalandırmanın, aktif havalandırma sistemine entegrasyonu da zorunlu tutulmaktadır. ${ }^{17}$

\section{ARAŞTIRMA YÖNTEMI}

Hangi havalandırma yönteminin çalışan memnuniyeti üzerinde daha olumlu etkilerinin olduğunu tespit edebilmek için; bu konuda yapılmış akademik çalışmaların incelenerek, çıkarımda bulunulması hedeflenmektedir.

Temel tanım ve kavramlardan görüldüğü üzere, faydalanılacak araştırmalarda, ele alınan binaların; iç hava koşullarının ölçülmüş ve sağlıklı kabul edilen sınırlar içerisinde kalıp kalmadığının tespit edilmiş olması ve ardından ilgili binalarda soru cevap yöntemi ile çalışanların memnuniyetlerinin ölçülmüş olması gerekmektedir. Bu şartları taşıyan araştırmaların sonuçlarından faydalanılarak, sağlıklı iç hava koşullarını sağlayan ve çalışan memnuniyeti bakımından en olumlu etkiyi oluşturan havalandırma yöntemi tespit edilmesi bede katkı sağlayacak bir çalışma olması beklenmektedir.

Ancak, sonuca ulaşılabilecek özelliklerde ve yeterli sayıda mevcut araştırmaya rastlanmaması halinde yeni bir veri toplama yönteminin önerilmesi, hedeflenen çalışmanın tamamlanması yönünde önemli bir yol alınmasını sağlayacağı düşünülmektedir.

\subsection{Literatür taraması}

Farklı havalandırma yöntemlerinin çalışan memnuniyeti üzerindeki farklı etkileri ile ilgili 2000-2019 seneleri arasında tarama yapıldığında; farklı havalandırma yöntemlerinin farklı enerji sarfiyatları ile ilgili çalışmalara sıklıkla rastlanmaktadır. Spesifik olarak havalandırma yönteminin çalışan memnuniyeti üzerindeki etkisinin, kullanıcı görüşmeleri ile desteklenerek tespit edildiği araştırmalar oldukça sınırı sayıdadır. Yine de görülmektedir ki, her bir araştırma havalandırma yöntemlerinden sadece birinin etkileri üzerinden ilerlemekte ve tespitlerde bulunmaktadır.

Farklı Havalandırma Yöntemlerinin, kullanıcı memnuniyeti üzerindeki farklı etkilerine yönelik en detaylı çalışma; 2001 Senesinde, Ankara'da yer alan Emek İşhanı'nın değiştirilen giydirme cephe sisteminde doğal havalandırma potansiyeli üzerinde iki açıdan gerçekleştirilen incelemedir. Aktif havalandırma sistemine entegre edilen pasif havalandırma ile ilgili sonuçlar elde edilebilmesi için, öncelikle bina kullanıcıları ile yapılan bir ankette, çalışanların iç ortamla ilgili görüşleri ve sağlık problemlerinin araştıııldığı görülmektedir. Yapılan ikinci çalışmada ise, binanın doğal havalandırma potansiyeli enerji kullanımı açısından incelenmektedir. Yapılan anket çalışmalarına göre, bina kullanıcılarının ciddi sağlık problemleri olduğu, kullanıcıların havalandırma sisteminin işleyişinden memnun olmadığı ve pek çoğunun iç ortam şartlarını ayarlamak için dışarıya pencere açma isteği bulunduğu belirtilmektedir. Çalışma kapsamında yapılan bilgisayar simülasyonuna göre, doğal havalandırmanın entegrasyonuyla, binanın yıllık enerji kullanımında önemli bir değişiklik olmamaktadır. Diğer taraftan, yaz ayları için binayı soğutmada kullanılan enerji giderleri ortadan kaldırılabilmektedir. Bu çalışmanın sonucunda, doğal havalandırma daha fazla kullanıcı memnuniyeti ve enerji tasarrufu için uygun bir araç olarak ortaya çıkmaktadır. ${ }^{18}$

\footnotetext{
${ }^{17}$ International Well Building Institute, The WELL Building Standard (v1 with Q3 2019 addenda), 2019, s. 22-60

${ }^{18}$ Uğursal, A., Integration of Natural Vantilation to Office Building Typology in the Ankara Context, Orta Doğu Teknik Üniversitesi, Fen Bilimleri Enstitüsü, Mimarlık Ana Bilim Dalı, Yüksek Lisans Tezi, Ankara, 2003 s.n.y.
} 
Yeşil ve yeşil olmayan üniversite binaları üzerinden, iç çevre koşulları ile kullanıcı memnuniyeti ilişkisinin incelendiği bir çalışmada ise, Avusturalya'da, Yeşil Bina Sertifikası (Green Star) almış binalardaki kullanıcıların bina tasarımı ve bina yönetimi açısından, yeşil bina sertifikası olmayan binalara göre daha memnun oldukları sonucuna ulaşılmaktadır. Bu çalışma kapsamında, iç çevre kalitesi değerlendirme ölçütleri esas alınarak, içerideki havanın tazeliği ve kokusu açısından, yeşil bina sertifikalı binalardaki memnuniyetin, sertifikası bulunmayan binalara (genellikle aktif havalandırması bulunmayan binalar) göre daha düşük, gürültü seviyesi, ısıtma, havalandırma, aydınlatma gibi faktörlerde ise yeşil binaların memnuniyet skorunun daha yüksek olduğu görülmektedir. ${ }^{19}$

Doğal havalandırmanın etkilerinin incelendiği bir diğer araştırmada ise, kütüphane kullanıcılarının memnuniyeti hedef alınmaktadır. Her ne kadar çalışan memnuniyeti kapsamından uzak görünse de, doğal havalandırmanın pozitif ve negatif etkileri üzerine bulgular sunulmaktadır. Kullanıcılar havalandırmadan memnuniyetleri için en yüksek puanlamayı verdiklerinde, gürültü açısından en düşük skora ulaşılmaktadır. ${ }^{20}$

\subsection{Literatür taramasından elde edilen sonuçlar}

Mevcut araştırmaların incelenmesi yöntemi ile hangi havalandırma sisteminin çalışan memnuniyeti üzerinde en olumlu etkiye sahip olduğunun tespit edilmesi konusunda yeterli verinin elde edilemeyeceği görülmektedir. Bu yönde bir görüşe ulaşılmasının sebebi aşağıda listelenmiştir.

a. Belirlenen kıstaslara sahip araştırma sayısı, sonuca ulaşılabilecek kadar fazla değildir.

b. Her araştırma bir havalandırma sistemi üzerinde durmuş ve bununla ilgili tespitlerde bulunmuştur.

c. Araştırmalar, kendi araştırdıkları yöntemin hem çalışan memnuniyeti, hem de enerji sarfiyatı bakımından doğru yöntem olduğu görüşünü bildirmektedirler.

d. Söz konusu araştırmaların sonuçları, araştırmaların yapıldığı şartlar içerisinde tutarlıdır. Ancak, araştırmaların coğrafya, tarih gibi şartlarının farklı olması sebebi ile, her birinden elde edilen verilerin karşılaştırma amaçlı olarak birlikte kullanılması söz konusu olamayacaktır.

$\mathrm{Bu}$ durumda, yeni bir veri toplama çalışması önerisi yapılmasının yerinde olacağı düşünülmektedir. Yukarıda sıralanan sebeplerin, yeni yöntem belirlenirken dikkat edilmesi gerekli bulgular olarak kullanılması planlanmaktadır..

\section{HAVALANDIRMA YÖNTEMLERININ OFIS ÇALIŞAN MEMNUNIYETI ÜZERINDEKI ETKILERININ TESPITI ÜZERINE VERI TOPLAMA YÖNTEM ÖNERISi}

Literatür taraması ile temel tanım ve kavramlardan elde edilen bulgular doğrultusunda önerilecek veri toplama yönteminin kapsamı ve bu kapsam dâhilinde; bina seçim kriterleri, ölçüm koşulları ve çalışan görüşmelerinin esaslarının belirlenmesi gerekmektedir.

\footnotetext{
${ }^{19}$ Khoshbakht, M., Gou, Z., Xie, X., He, B., Darko, A., Green Building Occupant Satisfaction: Evidence From the Australian Higher Education Sector - Sustainability 2018, 10, 2890 s.n.y.

${ }^{20}$ Said, A., Ahmad, M.H., Hamid, M., Enegbuma, W.I., A Users' Satisfaction on the Environmental Performance of Naturally Ventilated Library: A Structural Equation Modeling Approach, Indian Journal of Science and Technology, Vol 9(46), India, 2016. s.y.n.
} 


\subsection{Veri toplama yönteminin kapsamı}

- Veri toplama çalışmasına dahil edilecek binalar, aynı iklim koşulları içerisinde bulunmalıdırlar

- Yapılacak görüşmeler için seçilen çalışanlar, seçilen her binada aynı yüksekliğe karşılık gelen katta ve yönde konumlanmış olmalıdırlar.

- Değerlendirilebilir sonuç elde edilebilmesi için, çalışma hem aktif, hem pasif, hem de aktif/pasif entegre havalandırma yöntemine sahip binalarda yapılmalıdır.

- Veri çalışmasında her özellikteki binadan en az 2 adedinde çalışma yapılıp, her birinde en az 10 çalışan ile görüşülmesi şartı konulmalıdır.

- Çalışmanın kapsamını genişletmek için, aynı şartlara sahip, yeşil bina veya WELL sertifikası almış binalarda da veri toplanıp, değerlendirmeye alınabilir.

- Veri çalışması yapılacak binalarda, iç hava kalitesi ölçümlerinin yapılması ve hangi standarda göre değerlendirileceğine karar verilmesi gereklidir.

- Çalışma kapsamında yararlanılacak soruların öneri kapsamında yer alması gerekmektedir.

\subsection{Seçilecek binaların özellikleri}

Binaların aynı iklim özellikleri içerisinde kalabilmeleri için, aynı il sınırlarında seçilmeleri önemlidir. Aynı yöne hakim ve aynı katta çalışanlar ile görüşme yapılacağı için; binaların aynı adette kat sayısına minimumda sahip olması gerekmektedir.

İklim ve kat sayısı kriterleri sağlandıktan sonra, aşağıdaki havalandırma ve sertifika detaylarına göre, her gruptan en az ikişer bina seçilmeli ve izinler için başvurular yapılmalıdır:

\subsubsection{Standart veri toplama çalışması için bina seçimi}

- Tamamen aktif havalandırılan, sertifikası olmayan binalar

- Tamamen pasif havalandırılan binalar

- Doğal havalandırma entegrasyonu bulunan, ancak ana sistem olarak aktif havalandırılan, sertifikası olmayan binalar

\subsubsection{Genişletilmiş veri toplama çalışması için bina seçimi}

- Tamamen aktif havalandırılan, sertifikalardan birini almaya hak kazanmış binalar

- Doğal havalandırma entegrasyonu bulunan, ancak ana sistem olarak aktif havalandırılan, sertifikalardan birini almaya hak kazanmış binalar

\subsection{Seçilen binalarda yapılması gerekli iç hava kalitesi ölçümleri}

Kullanılabilir bir veri grubuna ulaşılabilmesi için en önemli şart, seçilen binalarda iç hava koşullarının sağlıklı sınırlar içerisinde kaldığından emin olmaktır. Bu nedenle;

- Sertifika sistemlerinden birini almaya hak kazanmış bir binada düzenli olarak iç kava kalitesi ölçümleri yapılmakta olduğundan, bina yönetiminin sağlayacağı değerler çalışma içerisinde kullanılabilecektir. 
- Aktif ya da aktif+pasif sistem entegrasyonu ile havalandırılan, bir sertifika sistemine dahil olmadığı halde, yine düzenli olarak iç hava kalitesi ölçümleri yapılan binalarda, bina verileri ile veri toplama çalışması kapsamında yapılacak ölçümün karşılaştırılıp, aynı çıkması halinde bina verilerinin kullanılması uygun olacaktır.

- Aktif+pasif sistem entegrasyonu ile havalandırılan, bina yönetimi tarafından iç hava kalitesi ölçümleri yapılmayan binalarda, çalışmayı gerçekleştiren kişi ya da kişiler tarafından ölçüm yapılması gerekmektedir.

- Pasif olarak havalandırılan binalarda da çalışmayı gerçekleştiren kişi ya da kişiler tarafından ölçüm yapılması gerekmektedir.

- Teslim alınması / Yapılması gereken Ölçümler:

- Ortam nemi ve sıcaklığı

- Havalandırmadan (aktif ya da pasif) kaynaklanan gürültü

- CO2 seviyesidir

Elde edilen veriler, hem farklı havalandırma özelliklerine sahip binaların kendi aralarındaki değerlendirmeleri hem de standartlara göre değerlendirmeleri bakımından önem taşımaktadır.

\section{4. Çalışanlar ile gerçekleştirilecek görüşmeler}

Çalışanlar ile gerçekleştirilecek görüşmelerin, verilerin sağlıklı bir şekilde değerlendirilebilmeleri için aşağıda önerildiği şekilde sınırlamaları olması gerektiği düşünülmektedir:

- Bina seçimleri ve iç hava kalitesi ölçümleri tamamlandıktan sonra, seçilen binaların her birinden en az on çalışanın seçilmesi öngörülmektedir.

- Veri toplama çalışmasını yapan kişi/kişiler tarafından belirlenmesi gereken değişken ise; çalışanların yaş ve cinsiyet dağılımlarıdır. Bu dağılım belirlendikten sonra, verilerin karşılaştırmasında tutarlıığın korunabilmesi için; her binadan aynı dağılımın sağlanmasına özen gösterilmesi gerekmektedir.

- Aynı veri toplama çalışması kapsamında, yine aynı binalar kullanılarak, çalışan yaş ve cinsiyet gruplamaları değiştirilmek suretiyle elde edilen verilerin genişletilmesi mümkün olacaktır.

- Belirlenen kullanıcıların özel ofislerinin olmaması, ortak çalışma alanında bulunmaları şartı aranması yine karşılaştırılabilir veriler toplanmasını sağlaması açısından önemlidir. Ancak yine özel ofisleri olan kullanıcıların da ek bir çalışma verisi olarak değerlendirilebileceği düşünülmektedir.

- Yukarıda belirlenen şartlara göre seçilmiş kullanıcıların her birinin bulundukları binaların havalandırma özelliklerine göre hazırlanmış soruları yanıtlamaları, açık uçlu sorular olması sebebi ile soru-cevap çalışmasının; karşılıklı görüşmeler ile yapılması önem taşımaktadır.

\subsection{Görüşme soruları}

Veri toplama çalışmasının; veriyi toplama aracı olan sorular, önceki bölümlerde aktarılan bilgilere uygun olarak hazırlanarak makale eki olarak sunulmaktadır. Veri toplama çalışması, standart ve genişletilmiş kapsamda önerilmekte olduğundan, anket soruları da bu kapsamlara uygun şekilde gruplandırılmaktadırlar. 


\section{DEĞERLENDIRME VE SONUÇ}

Çalışan memnuniyetinin nasıl sağlanacağına dair kesin bulgular bulunmamakla birlikte, memnuniyetsizliğinin önlenmesi daha belirgin bir konu olarak ortaya konmaktadır. Herzberg'in çift etmen teorisinde, hijyen faktörlerin kapsamında da üzerinde durulan bu durum, fiziksel çalışma şartlarının düzeltilmesi ile elde edilebilmektedir.

Çalışma ortamında sağlanması gereken havalandırma, aydınlatma, ısıtma/soğutma gibi fiziksel şartların sağlıklı olarak kabul edildiği aralıkları belirleyen standartlar ve bu standartların uygulanmasını denetleyen sistemler bulunduğu bilinmektedir. Sağlıklı çalışma ortamı olarak ölçülüp, kabul edilmiş değerler içerisinde kalan, ancak farklı yöntemlerle sağlanan havalandırmanın, çalışanlar üzerindeki etkisi de farklı olmaktadır. Hangi havalandırma sisteminin çalışan memnuiyeti için daha olumlu olduğunun tespit edilmesi ise, gelecekte ofis binası havalandırma projelerinde yöntem belirlenmesine katkıda bulunabilecek olması bakımından önemlidir.

Söz konusu tespitin yapılabilmesi amacı ile incelenen kavramlar ve literatür taramasının ardından elde edilen verilerin, nitelik ve nicelik olarak sonuç elde etmeye yeterli olmadığı görülmektedir. Bu durum bir taraftan hedeflenen ilk sonuca ulaşılmasını engellese de, yeni veri toplama modeli oluşturulması; ara tespit olarak ortaya konmaktadır. Bu çalışmada sonuca ulaşmaya yeterli olmayan veriler, yeni veri toplama çalışmasının kapsamanı belirlemekte kullanılmaktadır.

Detayları ile sunulan yeni veri toplama modelinin kullanılacağı ikinci bir çalışma ile havalandırma sistemlerinden hangisinin kullanıcı memnuniyetini daha olumlu etkilediğinin tespit edilebilmesi ve çalışmanın nihayetlendirilmesi mümkün olacaktır. 


\section{VERI TOPLAMA ÇALIŞMASI ANKET SORULARI - Standart Kapsam}

\section{GRUP1: TAMAMEN AKTIF HAVALANDIRILAN BINALARDA ÇALIŞAN KULLANICILAR}

1. Hangi tarihten beri bu binada çalışıyorsunuz

2. Cinsiyetiniz

3. Yaş aralığınız:
a. $20-30$
b. $30-45$
c. $45-60$
d. $60-75$

4. Üst solunum yolları ile ilgili kronik bir rahatsızlığınız var mı?
a. Hayır
b. Evet

i. Hayatınızı etkileme seviyesini aşağıdaki aralıkta değerlendir misiniz?

\begin{tabular}{|c|c|c|c|c|}
\hline 1 & 2 & 3 & 4 & 5 \\
\hline$A Z$ & & & & ÇOK \\
\hline
\end{tabular}

ii. Hangi tarihte başladı

iii. Binada bulunmaya başlama tarihiniz ile bağlantılı bir şiddet değişimi yaşadınız mı?

1. Hayır

2. Evet

a. Azaldı

\begin{tabular}{|c|c|c|c|c|}
\hline 1 & 2 & 3 & 4 & 5 \\
\hline $\mathrm{AZ}$ & & & & \multicolumn{1}{c|}{ çOK } \\
\hline
\end{tabular}

b. Arttı

\begin{tabular}{|c|c|c|c|c|}
\hline 1 & 2 & 3 & 4 & 5 \\
\hline$A Z$ & \multicolumn{4}{|c|}{} \\
\hline
\end{tabular}

5. Mevsimsel viral ya da mikrobik rahatsızlıklara sık yakalanıyor musunuz?

a. Yakalanmıyorum

b. Yakalanıyorum. Sıklığı

\begin{tabular}{|c|c|c|c|c|}
\hline 1 & 2 & 3 & 4 & 5 \\
\hline$A Z$ & & & \\
\hline
\end{tabular}

6. Havalandırmanın mekanik bir sistem ile yapılıyor olmasından memnun musunuz?
a. Evet - Neden?
b. Hayır - Neden?

7. Pencerelerin açılmasını ister miydiniz?
a. Evet
Neden?
b. Hayır - Neden?

8. Bu şirkette çalışmanız ile ilgili genel memnuniyet seviyeniz nedir?

\begin{tabular}{|c|c|c|c|c|}
\hline 1 & 2 & 3 & 4 & 5 \\
\hline$A Z$ & & & & çOK \\
\hline
\end{tabular}

9. Havalandırma şartları ile ilgili memnuniyet seviyeniz nedir?

\begin{tabular}{|c|c|c|c|c|}
\hline 1 & 2 & 3 & 4 & 5 \\
\hline$A Z$ & & & & ÇOK \\
\hline
\end{tabular}




\section{GRUP 2: TAMAMEN PASIF HAVALANDIRILAN BINALARDA ÇALIŞAN KULLANICILAR}

1. Hangi tarihten beri bu binada çalışıyorsunuz

2. Cinsiyetiniz

3. Yaş aralığınız
a. $20-30$
b. $30-45$
c. $45-60$
d. $60-75$

4. Üst solunum yolları ile ilgili kronik bir rahatsızlığınız var mı?

a. Hayır

b. Evet.

i. Hayatınızı etkileme seviyesini aşağıdaki aralıkta değerlendir misiniz?

\begin{tabular}{|c|c|c|c|c|}
\hline 1 & 2 & 3 & 4 & 5 \\
\hline$A Z$ & & & \multicolumn{1}{|c|}{} \\
\hline
\end{tabular}

ii. Hangi tarihte başladı

iii. Binada bulunmaya başlama tarihiniz ile bağlantılı bir şiddet değişimi yaşadınız mı?

1. Hayır

2. Evet

a. Azaldı

\begin{tabular}{|c|c|c|c|c|}
\hline 1 & 2 & 3 & 4 & 5 \\
\hline $\mathrm{AZ}$ & & & & $\mathrm{ÇOK}$ \\
\hline
\end{tabular}

b. Arttı

\begin{tabular}{|c|c|c|c|c|}
\hline 1 & 2 & 3 & 4 & 5 \\
\hline $\mathrm{AZ}$ & & & & $\mathrm{ÇOK}$ \\
\hline
\end{tabular}

5. Mevsimsel viral ya da mikrobik rahatsızlıklara sık yakalanıyor musunuz?

a. Yakalanmıyorum

b. Yakalanıyorum. Sıklığı

\begin{tabular}{|c|c|c|c|c|}
\hline 1 & 2 & 3 & 4 & 5 \\
\hline AZ & & & & çOK \\
\hline
\end{tabular}

6. Pencerelerin açılması suretiyle havalandırma yapılmasından memnun musunuz?
a. Evet -
Neden?
b. Hayır - Neden?

7. Havalandırmanın mekanik bir sistem ile yapılıyor olmasını ister miydiniz?
a. Evet - Neden?
b. Hayır - Neden?

8. Bu şirkette çalışmanız ile ilgili genel memnuniyet seviyeniz nedir?

\begin{tabular}{|c|c|c|c|c|}
\hline 1 & 2 & 3 & 4 & 5 \\
\hline$A Z$ & & & & ÇOK \\
\hline
\end{tabular}

9. Havalandırma şartları ile ilgili memnuniyet seviyeniz nedir?

\begin{tabular}{|c|c|c|c|c|}
\hline 1 & 2 & 3 & 4 & 5 \\
\hline $\mathrm{AZ}$ & & & & $\mathrm{ÇOK}$ \\
\hline
\end{tabular}




\section{GRUP 3: AKTIF HAVALANDIRILAN VE DOĞAL HAVALANDIRMA ENTEGRASYONU BULUNAN BINALARDA ÇALIŞAN KULLANICILAR}

1. Hangi tarihten beri bu binada çalışıyorsunuz

2. Cinsiyetiniz

3. Yaş aralığınız
a. $20-30$
b. $30-45$
c. $45-60$
d. $60-75$

4. Üst solunum yolları ile ilgili kronik bir rahatsızlığınız var mı?

a. Hayır

b. Evet.

i. Hayatınızı etkileme seviyesini aşağıdaki aralıkta değerlendir misiniz?

\begin{tabular}{|c|c|c|c|c|}
\hline 1 & 2 & 3 & 4 & 5 \\
\hline$A Z$ & & & & ÇOK \\
\hline
\end{tabular}

ii. Hangi tarihte başladı

iii. Binada bulunmaya başlama tarihiniz ile bağlantılı bir şiddet değişimi yaşadınız mı?

1. Hayır

2. Evet

a. Azaldı

\begin{tabular}{|c|c|c|c|c|}
\hline 1 & 2 & 3 & 4 & 5 \\
\hline $\mathrm{AZ}$ & & & & \\
\hline
\end{tabular}

b. Arttı

\begin{tabular}{|c|c|c|c|c|}
\hline 1 & 2 & 3 & 4 & 5 \\
\hline$A Z$ & & & & ÇOK \\
\hline
\end{tabular}

5. Mevsimsel viral ya da mikrobik rahatsızlıklara sık yakalanıyor musunuz?

a. Yakalanmıyorum

b. Yakalanıyorum. Sıklığı

\begin{tabular}{|c|c|c|c|c|}
\hline 1 & 2 & 3 & 4 & 5 \\
\hline AZ & & & & çOK \\
\hline
\end{tabular}

6. Havalandırmanın mekanik bir sistem ile yapılıyor olmasından memnun musunuz?
a. Evet
Neden?
b. Hayır - Neden?

7. Pencerelerin açılmasından memnun musunuz?
a. Evet
Neden?
b. Hayır - Neden?

8. Bu şirkette çalışmanız ile ilgili genel memnuniyet seviyeniz nedir?

\begin{tabular}{|c|c|c|c|c|}
\hline 1 & 2 & 3 & 4 & 5 \\
\hline$A Z$ & & & \multicolumn{1}{c}{ ÇOK } \\
\hline
\end{tabular}

9. Havalandırma şartları ile ilgili memnuniyet seviyeniz nedir?

\begin{tabular}{|c|c|c|c|c|}
\hline 1 & 2 & 3 & 4 & 5 \\
\hline $\mathrm{AZ}$ & & & & $\mathrm{çOK}$ \\
\hline
\end{tabular}


GRUP 4: TAMAMEN AKTIF HAVALANDIRILAN VE SERTIFIKA SISTEMLERINDEN BİRINI ALMAYA HAK KAZANMIŞ BİNALARDA ÇALIŞAN KULLANICILAR (Genişletilmiş Kapsam)

10. Hangi tarihten beri bu binada çalışıyorsunuz

11. Cinsiyetiniz

12. Yaş aralığınız:
e. $20-30$
f. $30-45$
g. $45-60$
h. $60-75$

13. Üst solunum yolları ile ilgili kronik bir rahatsızlığınız var mı?

a. Hayır

b. Evet.

i. Hayatınızı etkileme seviyesini aşağıdaki aralıkta değerlendir misiniz?

\begin{tabular}{|c|c|c|c|c|}
\hline 1 & 2 & 3 & 4 & 5 \\
\hline$A Z$ & & & $\longrightarrow$ & ÇOK \\
\hline
\end{tabular}

ii. Hangi tarihte başladı

iii. Binada bulunmaya başlama tarihiniz ile bağlantılı bir şiddet değişimi yaşadınız mı?

1. Hayır

2. Evet

a. Azaldı

\begin{tabular}{|c|c|c|c|c|}
\hline 1 & 2 & 3 & 4 & 5 \\
\hline $\mathrm{AZ}$ & & & $\rightarrow$ & $\mathrm{ÇOK}$ \\
\hline
\end{tabular}

b. Arttı

\begin{tabular}{|c|c|c|c|c|}
\hline 1 & 2 & 3 & 4 & 5 \\
\hline$A Z$ & & & $\rightarrow$ & ÇOK \\
\hline
\end{tabular}

14. Mevsimsel viral ya da mikrobik rahatsızlıklara sık yakalanıyor musunuz?

a. Yakalanmıyorum

b. Yakalanıyorum. Sıklığı

\begin{tabular}{|c|c|c|c|c|}
\hline 1 & 2 & 3 & 4 & 5 \\
\hline$A Z$ & & & $\longrightarrow$ & $C ̧ O K$ \\
\hline
\end{tabular}

15. Havalandırmanın mekanik bir sistem ile yapılıyor olmasından memnun musunuz?
a. Evet - Neden?

b. Hayır - Neden?

16. Pencerelerin açılmasını ister miydiniz?
a. Evet -
Neden?
b. Hayır -
Neden?

17. Bu şirkette çalışmanız ile ilgili genel memnuniyet seviyeniz nedir?

\begin{tabular}{|c|c|c|c|c|}
\hline 1 & 2 & 3 & 4 & 5 \\
\hline $\mathrm{AZ}$ & & & $\longrightarrow$ & $\mathrm{ÇOK}$ \\
\hline
\end{tabular}

18. Havalandırma şartları ile ilgili memnuniyet seviyeniz nedir?

\begin{tabular}{|c|c|c|c|c|}
\hline 1 & 2 & 3 & 4 & 5 \\
\hline $\mathrm{AZ}$ & & & $\longrightarrow$ & $\mathrm{ÇOK}$ \\
\hline
\end{tabular}




\section{GRUP 5: AKTIF HAVALANDIRILAN, DOĞAL HAVALANDIRMA ENTEGRASYONU BULUNAN VE SERTIFIKA SISTEMLERINDEN BIRINI ALMAYA HAK KAZANMIŞ BINALARDA ÇALIŞAN KULLANICILAR}

10. Hangi tarihten beri bu binada çalışıyorsunuz

11. Cinsiyetiniz

12. Yaş aralığınız
e. $20-30$
f. $30-45$
g. $45-60$
h. $60-75$

13. Üst solunum yolları ile ilgili kronik bir rahatsızlığınız var mı?
a. Hayır
b. Evet

i. Hayatınızı etkileme seviyesini aşağıdaki aralıkta değerlendir misiniz?

\begin{tabular}{|c|c|c|c|c|}
\hline 1 & 2 & 3 & 4 & 5 \\
\hline$A Z$ & & & & ÇOK \\
\hline
\end{tabular}

ii. Hangi tarihte başladı

iii. Binada bulunmaya başlama tarihiniz ile bağlantılı bir şiddet değişimi yaşadınız mı?

1. Hayır

2. Evet

a. Azaldı

\begin{tabular}{|c|c|c|c|c|}
\hline 1 & 2 & 3 & 4 & 5 \\
\hline$A Z$ & & & & çOK \\
\hline
\end{tabular}

b. Arttı

\begin{tabular}{|c|c|c|c|c|}
\hline 1 & 2 & 3 & 4 & 5 \\
\hline$A Z$ & \multicolumn{4}{|c|}{} \\
\hline
\end{tabular}

14. Mevsimsel viral ya da mikrobik rahatsızlıklara sık yakalanıyor musunuz?

a. Yakalanmıyorum

b. Yakalanıyorum. Sıklığı

\begin{tabular}{|c|c|c|c|c|}
\hline 1 & 2 & 3 & 4 & 5 \\
\hline$A Z$ & & & \\
\hline
\end{tabular}

15. Havalandırmanın mekanik bir sistem ile yapılıyor olmasından memnun musunuz?
a. Evet - Neden?
b. Hayır - Neden?

16. Pencerelerin açılmasından memnun musunuz?
a. Evet - Neden?
b. Hayır - Neden?

17. Bu şirkette çalışmanız ile ilgili genel memnuniyet seviyeniz nedir?

\begin{tabular}{|c|c|c|c|c|}
\hline 1 & 2 & 3 & 4 & 5 \\
\hline $\mathrm{AZ}$ & \multicolumn{4}{|c|}{} \\
\hline
\end{tabular}

18. Havalandırma şartları ile ilgili memnuniyet seviyeniz nedir?

\begin{tabular}{|c|c|c|c|c|}
\hline 1 & 2 & 3 & 4 & 5 \\
\hline$A Z$ & & & & ÇOK \\
\hline
\end{tabular}




\section{KAYNAKLAR}

Erten, D., Yeşil Bina Raporu, Sürdürülebilir Üretim ve Tüketim (REC)Yayınları, https://recturkey.files.wordpress.com/2017/02/yesil-binalar.pdf, 08.01.2020.

Yüksek, İ., Esin, T., Yapılarda Enerji Etkinliği Bağlamında Doğal Havalandırma Yöntemlerinin Önemi, Tesisat Mühendisliği, Sayı 125, İstanbul, 2011

Telman, N., Ünsal, P., Çalışan Memnuniyeti, Epsilon Yayınevi, İstanbul, 2004.

Çabukel, R., Çalışan Memnuniyeti Analizleri, İstanbul Üniversitesi, Soysal Bilimler Enstitüsü, Çalışma Ekonomisi ve Endüstri İlişkileri Ana Bilim Dalı, Yüksek Lisans Tezi, İstanbul, 2008.

Polat, A., Mekanik Tesisat Komisyonu, Havalandırma ve İklimlendirme Semineri, TMMOB, İzmir, 2017.

ASHVAE Founding Meeting 1894, https://www.ashrae.org/about/mission-andvision/ashrae-industry-history, 10.01.2020.

Bulgurcu, H., Havalandırma Tekniği, Balıkesir, 2015 , https://silo.tips/download/havalandirma-tekn-do-dr-hseyin-bulgurcu-balkesir-2015\#, 10.01.2020.

Hava Kalitesi Değerlendirme ve Yönetimi Yönetmeliği, 2008, Resmî Gazete, 26898, 06.06.2008.

Çilingiroğlu, S., İç Hava Kalitesi, Tesisat Mühendisliği Dergisi, İstanbul, 2010. s. 23-42 Proje (Mekanik, Tesisat, Asansör, A.I.T.M.) Hazırlama ve Mesleki Denetim Esasları, TMMOB Makine Mühendisleri Odası, Ankara, 2008.

Görgün, B., Enerji Verimli Yeşil Bina Sertifikasyonunda Yol Haritasının Belirlenmesi İçin LEED ve BREEAM Örneklerinin İncelenmesi, İstanbul Teknil Üniversitesi, Fen Bilimleri Enstitüsü, Mimarlık Ana Bilim Dalı, Yüksek Lisans Tezi, İstanbul, 2012.

Watt, M., Understanding LEED, WELL and the Differences, https://eponline.com/articles/2019/04/11/understanding-leed-well-and-thedifferences.aspx , 04.01.2020 s.1

International Well Building Institute, The WELL Building Standard (v1 with Q3 2019 addenda), 2019, s. 22-60

Uğursal, A., Integration of Natural Vantilation to Office Building Typology in the Ankara Context, Orta Doğu Teknik Üniversitesi, Fen Bilimleri Enstitüsü, Mimarlık Ana Bilim Dalı, Yüksek Lisans Tezi, Ankara, 2003

Khoshbakht, M., Gou, Z., Xie, X., He, B., Darko, A., Green Building Occupant Satisfaction: Evidence From the Australian Higher Education Sector - Sustainability, Avustralya, 2018

Said, A., Ahmad, M.H., Hamid, M., Enegbuma, W.I., A Users' Satisfaction on the Environmental Performance of Naturally Ventilated Library: A Structural Equation Modeling Approach, Indian Journal of Science and Technology, Vol 9(46), India, 2016. s.y.n. 